\title{
Mandatory HPV Vaccination and Political Debate
}

Lawrence O. Gostin

Georgetown University Law Center, gostin@law.georgetown.edu

Georgetown Public Law and Legal Theory Research Paper No. 11-128

This paper can be downloaded free of charge from:

https://scholarship.law.georgetown.edu/facpub/694

http://ssrn.com/abstract=1945958

306 JAMA 1699-1700 (2011)

This open-access article is brought to you by the Georgetown Law Library. Posted with permission of the author. Follow this and additional works at: https://scholarship.law.georgetown.edu/facpub

Part of the Health Law and Policy Commons, Health Policy Commons, Law and Politics Commons, Other Public Health Commons, and the Sexuality and the Law Commons 


\section{Mandatory HPV Vaccination and Political Debate}

\section{Lawrence O. Gostin, JD}

V ACCINATIONS ARE AMONG THE MOST COSTeffective and widely used public health interventions but have provoked popular resistance, with compulsory vaccination framed as an unwarranted state interference. When the US Food and Drug Administration (FDA) approved a human papillomavirus (HPV) vaccine in 2006, conservative religious groups strongly opposed a mandate, arguing it would condone premarital sex and undermine parental rights. Yet Governor Rick Perry signed an executive order in 2007 making Texas the first state to enact a mandate-later revoked by the state legislature.

Mandatory HPV vaccination received additional attention during a recent debate among Republican presidential candidates. Michele Bachmann, US representative from Minnesota, Rick Santorum, former US senator from Pennsylvania, and Governor Perry had spirited exchanges about the executive order that Perry issued in 2007. Bachmann called the vaccine "a dangerous drug" and Santorum added, "There is no government purpose served for having little girls inoculated at the force and compulsion of the government." Perry almost immediately disavowed his action, saying first that the vehicle of an executive order was wrong and then that vaccination should be "opt-in."

Comments such as these could cause parents to decide not to have their children vaccinated, thereby potentially leading to preventable illness and perhaps even death. The scientific evidence demonstrates that population-based HPV vaccination is safe and effective, justifying widespread adoption of the vaccine. The question is whether a state mandate would increase vaccination rates or result in a backlash not only against HPV vaccination but also wider childhood vaccinations. Given the political divisiveness, states should launch health education campaigns before resorting to compulsion.

\section{HPV Vaccine Effectiveness and Safety}

Human papillomavirus infection and HPV-associated cancers pose a major public health threat. Human papillomavirus is the most common sexually transmitted infection in the United States, with an estimated 20 million individuals currently infected and 6.2 million newly infected annually. ${ }^{2}$ The HPV prevalence among girls and women is $26.8 \%$ overall, with increasing prevalence each year from ages 14 to 24 years ( $44.8 \%$ for ages $20-24$ years), followed by a gradual decline through age 59 years; high-risk HPV types are detected in only $3.4 \%$ of women tested. ${ }^{2}$

Nononcogenic HPV types 6 and 11 are associated with genital warts and recurrent respiratory papillomatosis. Highrisk HPV types are detected in virtually all cervical, vaginal, and vulvar cancers in women, and HPV types 16 and 18 are associated with $70 \%$ of cervical cancers. Each year, more than 12000 new cervical cancer cases are diagnosed in the United States, with more than 4000 deaths from cervical cancer occurring annually. ${ }^{3}$ Human papillomavirus also is associated with cancer of the penis, as well as cancers of the oropharynx and anus in both women and men. Persons with lower education and higher poverty experience disproportionate burdens of HPV-associated cancers.

In June 2006, the FDA licensed a prophylactic quadrivalent HPV vaccine against HPV types 6, 11, 16, and 18 for use among girls and women aged 9 to 26 years. ${ }^{4}$ In October 2009 , the FDA approved a bivalent vaccine against HPV types 16 and $18 .{ }^{5}$ The Advisory Committee on Immunization Practices (ACIP) recommends routine quadrivalent or bivalent vaccination of girls aged 11 or 12 years with 3 doses that can start at age 9 years. The ACIP recommends "catch-up" vaccination for girls and women aged 13 to 26 years who have not been previously vaccinated. Quadrivalent HPV vaccine may be given to boys and men aged 9 to 26 years. ${ }^{6}$ Ideally, vaccination should begin before sexual activity.

Numerous public health organizations including the Centers for Disease Control and Prevention, the American Academy of Pediatrics, and the American Academy of Family Physicians endorse HPV vaccination for young women. Although clinical trial evidence has not demonstrated prevention of invasive cervical cancer from $\mathrm{HPV}$ vaccination, it has shown that the vaccine is almost 100\% effective in preventing infections associated with HPV types included in the vaccine.

The HPV vaccine has an impressive safety profile. More than 29000 male and female individuals have participated in quadrivalent vaccine trials, more than 30000 girls and women have participated in bivalent vaccine trials, and an estimated 35 million vaccine doses have been administered in the United States.

Author Affiliation: O'Neill Institute for National and Global Health Law, Georgetown University, Washington, DC.

Corresponding Author: Lawrence O. Gostin, JD, O'Neill Institute for National and Global Health Law, Georgetown University Law Center, 600 New Jersey Ave NW, Washington, DC 20001 (gostin@law.georgetown.edu). 
Adverse effects were minor and similar to those found with most vaccines, such as dizziness, fainting, and injection site reactions. Serious systemic adverse reactions are rare and certainly do not include mental retardation as Bachmann implied. As of June 22, 2011, the Vaccine Adverse Event Reporting System had not confirmed serious adverse effects greater than background rates. ${ }^{7}$

\section{Are State Mandates Effective?}

Although 41 states have introduced legislation related to HPV vaccine, only Texas (revoked), Virginia, and the District of Columbia have enacted HPV vaccine mandates. Both Virginia and the District of Columbia offer generous "opt-outs" at parents' "discretion." Yet 20 states have laws to fund vaccines or educate the public, and health departments in New Hampshire, South Dakota, and Washington distribute free vaccines. ${ }^{8}$ Since research on the effectiveness of mandates is unavailable, the critical question is whether state laws actually increase vaccination rates. The kind of mandate also must be considered, as generous "opt-outs" may mean little positive effect. However, mandates may be premature because of drug company lobbying, public backlash, gender equity, and cost.

Drug Company Lobbying. Following FDA approval of the quadrivalent vaccine, the manufacturer (Merck) lobbied for compulsory vaccination laws. During the Republican debate, Governor Perry denied Merck's political influence, stating that he received only $\$ 5000$. However, Merck donated $\$ 28500$ to his gubernatorial campaign and an additional $\$ 377500$ to the Republican Governors Association, for which Perry served as chairman. ${ }^{1}$ Furthermore, Merck's lobbyist at the time of the executive order was Governor Perry's former chief of staff. Merck's lobbying is concerning and fuels public distrust of lawmakers' objectivity in enacting compulsory vaccination.

Public Backlash. There are special reasons HPV mandates might provoke a public backlash, with a combination of socially divisive implications-adolescent sex, bodily integrity, and parental responsibility. There is no evidence that HPV vaccines increase sexual activity among adolescents, but this aspect of mandatory vaccination is a political hot button. State mandates override parental consent, fueling long-standing antivaccination movements. Moreover, HPV vaccination is different than most diseases warranting compulsion because the virus is not airborne and does not pose immediate risks of transmission through casual contact among adolescents, such as in schools.

Gender Equity. Although the ACIP permits male HPV vaccination, government recommendations are directed solely toward young women. The HPV vaccine is the first mandated for only 1 gender. Yet men have equally high HPV rates and are as likely to transmit the infection to partners. Men are at risk of virus-associated warts and cancers. Reducing HPV prevalence among men will also decrease transmission of HPV infection to women. Although gender distinctions are justified by differences in available data, lack of gender equity remains ethically troubling. Is it fair if young girls are compelled to submit to a new vaccine as a condition of publicly funded education when boys are not?
Cost. The HPV vaccine is among the most costly, with a price of $\$ 360$ for 3 doses. ${ }^{9}$ At the same time, HPV-related diseases are estimated to cost at least $\$ 4$ billion in direct medical expenses (not including lost productivity) annually. ${ }^{9}$ Who will pay for mandated HPV vaccines and what other public health services would society have to forego? State health departments have decreasing budgets with expanded missions. Physicians also must pay for vaccines and wait for private or public reimbursement, placing further strain on the health care system.

Human papillomavirus vaccination rates lag far behind other adolescent vaccinations, increasing to only $32 \%$ in $2010 .{ }^{10}$ Government should implement a well-funded campaign to increase HPV vaccination rates as part of a comprehensive sexually transmitted infection prevention package: pay for the vaccine or require public or private coverage; launch health education and social marketing campaigns; and reduce associated harms through early screening and treatment. If voluntary vaccination proves unsuccessful, states should seriously consider compulsory vaccination laws without generous exemptions. For now, maintaining public trust is vital both for HPV vaccination and for the viability of school-based vaccination programs. Above all, health policy must be driven by science. Political leaders have a moral responsibility to ensure their political advocacy is well informed and does not cause future harm to America's youth.

Published Online: October 6, 2011. doi:10.1001/jama.2011.1525

Conflict of Interest Disclosures: The author has completed and submitted the ICMJE Form for Disclosure of Potential Conflicts of Interest and none were reported.

Additional Contributions: John Kraemer, JD, MPH, Lisa Eckstein, SJD candidate, and Kelli Garcia, JD, provided valuable research and editing. No compensation was received.

\section{REFERENCES}

1. McGreal C, Sample I. Michele Bachmann HPV row prompts fears for vaccine programme in US. September 14, 2011. http://www.guardian.co.uk/world/2011 /sep/14/michele-bachmann-hpv-vaccine. Accessed September 27, 2011.

2. Dunne EF, Unger ER, Sternberg M, et al. Prevalence of HPV infection among females in the United States. JAMA. 2007;297(8):813-819.

3. National Cancer Institute. Cervical cancer. http://www.cancer.gov/cancertopics /types/cervical. Accessed September 27, 2011.

4. Markowitz LE, Dunne EF, Saraiya M, Lawson HW, Chesson H, Unger ER; Centers for Disease Control and Prevention; Advisory Committee on Immunization Practices. Quadrivalent human papillomavirus vaccine: recommendations of the Advisory Committee on Immunization Practices (ACIP). MMWR Recomm Rep. 2007;56(RR-2):1-24.

5. Centers for Disease Control and Prevention. FDA licensure of bivalent human papillomavirus vaccine (HPV2, Cervarix) for use in females and updated HPV vaccination recommendations from the Advisory Committee on Immunization Practices (ACIP). MMWR Morb Mortal Wkly Rep. 2010;59(20):626-629.

6. Centers for Disease Control and Prevention. FDA licensure of quadrivalent human papillomavirus vaccine (HPV4, Gardasil) for use in males and guidance from the Advisory Committee on Immunization Practices (ACIP). MMWR Morb Mortal Wkly Rep. 2010;59(20):630-632.

7. Centers for Disease Control and Prevention. Reports of health concerns following HPV vaccination. August 2011. http://www.cdc. gov/vaccinesafety/vaccines /hpv/gardasil.html. Accessed September 27, 2011.

8. National Conference of State Legislatures. HPV vaccine: state legislation and statutes. September 2011. http://www.ncsl.org/default.aspx?tabid=14381. Accessed September 27, 2011.

9. Insinga RP, Dasbach EJ, Elbasha EH. Assessing the annual economic burden of preventing and treating anogenital human papillomavirus-related disease in the US: analytic framework and review of the literature. Pharmacoeconomics. 2005; 23(11):1107-1122.

10. Centers for Disease Control and Prevention. National and state vaccination coverage among adolescents aged 13 through 17 years-United States, 2010 MMWR Morb Mortal Wkly Rep. 2011;60(33):1117-1123. 